\title{
IMPACT OF ISO TOTAL QUALITY MANAGEMENT PRINCIPLES ON DEPARTMENT OF MUNICIPAL AFFAIRS AND TRANSPORT
}

\author{
Marwa Naji Ali Alkhater Albuainaini, \\ Ali Khatibi, \\ S. M. Ferdous Azam, \\ Jacqueline Tham \\ Postgraduate Centre (PGC), \\ Management \& Science University (MSU), \\ Shah Alam, Malaysia
}

\begin{abstract}
:
Total quality management (TQM) is a collection of strategies for constantly improvement inside organisations. The government of UAE has made considerable measures towards the adoption of TQM. Despite that, many organisations in UAE are not able to adopt the principles of TQM. The purpose of this study is to explore the influence of TQM principles proposed by the International Organization for Standardization on Department of Municipal Affairs and Transport quality. This study employed quantitative technique to address research questions. The conclusion of this study reveals that department of municipal affairs and transport industries need to adopt the principles of TQM according to the seven principles of ISO to achieve high Department of Municipal Affairs and Transport Quality. This study recommends that transport industries in UAE should establish a department of quality office in each college headed by specialist managers in TQM who will be responsible for following-up and monitoring the application of TQM like continuous improvement, teamwork spirit, and sharing decision-making.
\end{abstract}

JEL: H12; H50

Keywords: Total Quality Management (TQM), Department of Municipal Affairs and Transport Quality, International Standardization Organization (ISO)

\section{Introduction}

Total Quality Management (TQM) is a management concept that focuses on current management activities that allow an organisation to achieve high levels of service and product quality. TQM is founded on a number of contemporary ideas and philosophies

${ }^{i}$ Correspondence: email marwa.albuainain@gmail.com 
that combine fundamental administrative procedures, specific technical abilities, and inventive attempts to continuously improve the level of quality in many organisational areas (Khadijah et al., 2016).

The importance of quality improvement and assessment in public administration has resulted in the creation and use of strategic models. In the industrial business, total quality control may be tracked. With the growing need for quality services in the public sector in the UAE, TQM and excellence awards have become critical. This is because the fundamental problem with TQM is that service organisations have continued to confront severe realities comparable to those encountered by manufacturing organisations. This is the fundamental rationale for the usage of service quality models. The stages in service quality management may improve service delivery efficiency and customer happiness, while setting the strategic groundwork for technology integration and innovation. Due to the impact of a lack of service quality, the emergence of complaints related to poor time service, service delivery delays, and a lack of performance measurement, the department of municipal affairs and transport has been forced to provide value added services to customers and demonstrate a strong commitment to quality service in service to support its business success.

The research demonstrates the critical significance of service quality provision in principles of customer satisfaction and perceptions. In the UAE's public administration, the majority of departments within Dubai municipal have emphasised the dimension of perception as being anchored on the provision of high-quality services from the customer service and service delivery perspectives. This inference reinforces the dimension that the complete service quality assessment is linked to the restaurant's and hotel's capacity to provide superior services. The establishment and maintenance of service quality has farreaching financial implications, which the department of municipal affairs and transport may use as a strategic instrument for competitive advantage.

The relationship between service quality provision and customer satisfaction is dependent on the harmonious relationship established between the department of municipal affairs and transport and its customers, the integration of technology to leverage the basis for service delivery, and the implication of service benefit to address the strategic importance of quality (Kumar, 2009; Prabha, 2011; Azam and Moha Asri, 2015). Essentially, continual quality improvement is an investment strategy that public administration may use to increase profits and sales volume (Tham et al., 2017; Udriyah et al., 2019).

\section{Literature Review}

Five variables contribute to the quality of service provision: responsiveness, tangibility, assurance, dependability, and empathy. All of the aforementioned aspects have aided the municipality's ability to include the customer in the provision of high-quality services in the UAE. Brown and Marchal (2008) asserted that customer satisfaction is determined by the consumers' perceptions of the service they get, particularly in terms of quality. This 
sense of quality is in comparison to the customer expectations for services in comparison to other organisations in the public sector. As such, anticipating customer wants and being able to meet those needs is critical to establishing service quality since it results in increased earnings in comparison to municipalities that fail in this area.

Total quality management enables the department of municipal affairs and transport to guarantee that the organization's priorities and attention are provided toward the customers' expectations and perceptions of the services delivered to them (Brown and Marchal, 2008). This establishes a quality service standard that aids towns in understanding market expectations. According to the Asian Productivity Organization (2021), holistic quality management principles analyse the notion that customer satisfaction is important to service standards. This is accomplished by balancing the consumers' expectations and perceptions of the quality of the services provided. The department of municipal affairs and transportation will use AAA Diamond Rating Standards and Reliability service standards to bolster key skills and so fulfil market expectations. This dependability service standard assures that the municipality provides high-quality services on time, which is a critical component of service quality. This is because it is a strategic element of services to be provided in a way that assures priority, allowing for the production of services on demand while also guaranteeing that the gap between demand and time the service is rendered is timely (Haque et al., 2014; Rachmawati et al., 2019). The municipal decreases the time required to grab the customer's attention by reducing the time spent in the line and waiting to be serviced.

The criteria for evaluating a possible strategic plan alternative are predicated on the need to implement strategic solutions. The criteria include lowering obstacles and overcoming opposition, allocating resources to capabilities, and furthering the organization's objective. Such criteria include understanding the strategy's effectiveness in order to determine the likelihood that the solution will achieve the desired outcomes, evaluating the strategic plan's feasibility in terms of time, cost, and resource capabilities. This will be accomplished efficiently by developing a balanced scorecard and decision matrix for each of the strategy solutions. Understanding internal and external forces lays the groundwork for establishing defined criteria for corporate success.

Total quality management is predicated on quality planning. The product's quality and achievement of the strategic aim will be determined by the organization's ability to continue delivering effective and sustainable public service. At this phase, risk to success must be assessed, standards established, documentation created, and procedures and tests defined for attaining, managing, predicting, and validating plan success.

The municipal quality assurance exam will use a metric-based method to verify whether the quality plan is progressing in the proper way. It is significant to test the quality assurance procedures in the department of municipal affairs and transport, as well as the project; both qualitative and quantitative metrics are critical in determining the product's quality and customer satisfaction. The tests will aid in predicting and validating achievement attainment, as well as highlighting areas in need of remedial action. The mechanics of quality control refer to the operational approaches used to 
ensure that quality standards are met. This stage in the municipality will concentrate on the identification, analysis, and rectification of errors; this aspect of quality management is often reactive and occurs in response to the identification of a problem. During this stage, certain outputs will be monitored and compliance with applicable standards determined (Tarofder et al., 2019). The measurements are used to monitor the quality and operational processes with the goal of assessing if desired outcomes, such as compliance with the organization's quality goals and targets, are being accomplished (Brown and Marchal, 2008). This is significant in ensuring that corrective measures are taken to lead the quality goals in the desired direction.

\subsection{The Principles of Total Quality Management}

Quality is a term that carries important meaning to both producer and customer. In the global marketplace today, many organizations realized that its survival in the business world depend highly on producing high quality product and services. In business, engineering and manufacturing, quality has a pragmatic interpretation as the noninferiority or superiority of something; it is also defined as fitness for purpose. Quality is a perceptual, conditional, and somewhat subjective attribute and may be understood differently by different people (Azam et al., 2014; Elias, 2015; Haur et al., 2017; Tarofder et al., 2017; Katukurunda et al., 2019).

Total quality management (TQM) consists of organization-wide efforts to install and make permanent a climate in which an organization continuously improves its ability to deliver high-quality products and services to customers (De Silva et al., 2017; Kuruwitaarachchi et al., 2019; Pambreni et al., 2019). The TQM philosophy provides the overall concept that fosters continuous improvement in organizations. Continuous improvements can be achieved through internal and external quality improvements (Dahlgaard et al., 1998; Jayasuriya and Azam, 2017; Dewi et al., 2019; Nguyen et al., 2019).

Moreover, TQM is a management philosophy, a paradigm, a continuous improvement approach to doing business through a new management model. The TQM philosophy evolved from the continuous improvement philosophy with a focus on quality as the main dimension of business. Under TQM, emphasizing the quality of the product or service predominates. TQM expands beyond statistical process control to embrace a wider scope of management activities of how we manage people and organizations by focusing on the entire process, not just simple measurements (Rad, 2006).

\subsection{The Principles of ISO}

ISO is a term is derived from the origin of Greek word ISOS, which means parity or equal (ISO, 2004:2), it is used as a prefix in some words on the concept of a parity and equality (International Standardization Organization, 2004). The ISO (9000) family of quality management systems standards is designed to help organizations ensure that they meet the needs of customer's quality requirement (Maghfuriyah et al., 2019; Pushpakumara et al., 2019), while meeting statutory and regulatory requirements related to a product or 
program. ISO (9000) deals with the fundamentals of quality management systems (Poksinska, 2002), including the seven quality management principles upon which the family of standards is based deals with the requirements that organizations wishing to meet the standard must fulfil (International Organization for Standardization, 2015).

ISO quality standards are characterized by the following:

1. Customer Focus. Organizations and companies focus much on their customers and this knowledge of the current and future needs of customers is very important and must meet their high accuracy and quality exceed their expectations to achieve success in the work.

2. Leadership. Leaders are responsible to establish unity within the organization in order to support the employees and the organization or industry in one direction specified a path of leaders to sustain the internal work environment and encourage employees to achieve organization's goals.

3. Engagement of People. Employees and workers at all levels are the essence of the center of organizations and their full participation to use their abilities for the benefit of their organization should be reflected on the overall performance and achieve success.

4. Relationships Management. This principle is important to achieve the desired result from work through more efficiently when activities and resources are managed as a relevant organization and programmed process. Applying this principle basically leads to systematic identification necessary to get the desired result of activities and identification of responsibility and accountability are clear for the management of the main activities.

5. Process Approach. This principle helps the organization to identify, understand and manage interrelated processes so that contributes to the organization's effectiveness and efficiency. The result of applying this principle is important to achieve the objectives that are reflected on the quality of the performance.

6. Continuous Improvement. Every organization needs for continuous development in the overall performance to fulfil the objectives of the organization and accomplish its priorities because through continuous improvement the performance is developed on a regular basis. Continuous improvement typically leads to consistency in work within the organization. To achieve this principle, it is necessary to provide training to workers on the methods and tools that develop their skills to do the work.

7. Decision-making Process. Decisions makers do effective decision based on provided data and information, they need accurate information on the functioning of the organization in general and staff and the performance. All these details are very important for decision making process by senior management.

This study assumes that the seven principles of quality of ISO have a direct effect on Department of Municipal Affairs and Transport quality. Figure 1 illustrates the relationships between the independent and dependent variables. 


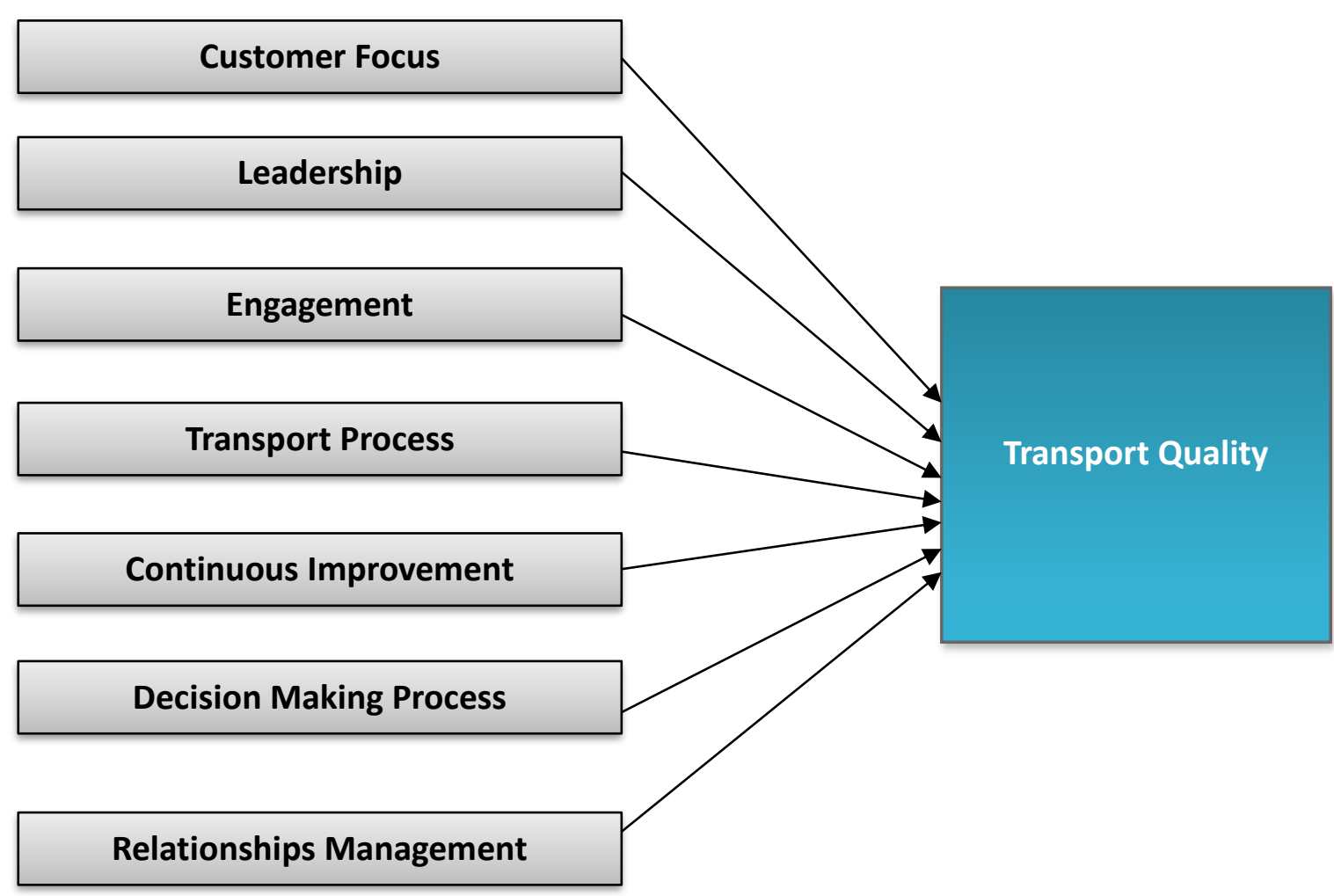

Figure 1: Department of Municipal Affairs and Transport Quality Theoretical Model

\section{Methodology}

As described above, this study used quantitative methods to get empirical evidences in order to examine the hypotheses of study. The design of this study is developed for testing the hypothesis and conducting a literature review of available studies and data, or both (Adèrand Hand, 2008). SEM approach was applied in order to measure the significance of each hypothesis. The respondents of this study consists of individuals represent transport industry staffs, clients, and users. As developed by Sekaran (2003), to determine a population of approximately 1620 as approximate number of participants = 31 according to Sekaran (2003). The number was increased to 400 to increase the reliability of data. The valid forms used in the analysis $=392$ after withdrawal non-complete questionnaires.

\subsection{Data Analysis}

To test the hypotheses of the study, structural equation modelling (SEM) is used. In SEM, independent variable (ISO factors) is referred to as exogenous variables while dependent variable (Department of Municipal Affairs and Transport Quality) is referred to as endogenous variable (Browne and Cudeck, 1993).

Critical Ration (C.R) is the statistical indicator used in this study to validate each hypothesis. C.R is formed by the formula of dividing an estimate by its standard error, 
thus if C.R. value range between 1.96 or higher (and -1.96 and lower), specifies significance relationship. In other words, the hypothesis is considered true

- Hypothesis 1: A statistical association exists between Customer Focus and Department of Municipal Affairs and Transport Quality. It is found that Customer Focus correlate significantly with Department of Municipal Affairs and Transport Quality because C.R value $=2.308 \geq 1.96$. Furthermore, C.R positive value is statistically significant ( $\left.\mathrm{Q} \leq 0.000,{ }^{* * *}\right)$.

- Hypothesis 2: A statistical association exists between Leadership and Department of Municipal Affairs and Transport Quality. It is found that Leadership correlates significantly with Department of Municipal Affairs and Transport Quality because C.R value $=4.983 \geq 1.96$. Furthermore, C.R positive value is statistically significant $\left(\mathrm{Q} \leq 0.000,{ }^{* * *}\right)$.

- Hypothesis 3: A statistical association exists between Engagement of people and Department of Municipal Affairs and Transport Quality. It is found that Engagement of people correlate significantly with Department of Municipal Affairs and Transport Quality because C.R value $=3.767 \geq 1.96$.

- Hypothesis 4: A statistical association exists between Transport Process Approach and Department of Municipal Affairs and Transport Quality. It is found that Department of Municipal Affairs and Transport Process Approach correlate significantly with Department of Municipal Affairs and Transport Quality because C.R value $=2.237$ $\geq 1.96$. Furthermore, C.R positive value is statistically significant $\left(\mathrm{Q} \leq 0.000,{ }^{* *}\right)$.

- Hypothesis 5: A statistical association exists between Continuous Improvement and Department of Municipal Affairs and Transport Quality. It is found that Continuous Improvement correlate significantly with Department of Municipal Affairs and Transport Quality because C.R value $=3.105 \geq 1.96$. Furthermore, C.R positive value is statistically significant $\left(\mathrm{Q} \leq 0.000,{ }^{* * *}\right)$.

- Hypothesis 6: A statistical association exists between Decision Making Process and Department of Municipal Affairs and Transport Quality. It is found that Decision Making Process correlate significantly with Department of Municipal Affairs and Transport Quality because C.R value $=4.820 \geq 1.96$. Furthermore, C.R positive value is statistically significant $\left(\varrho \leq 0.000,{ }^{* * *}\right)$.

- Hypothesis 7: A statistical association exists between Relationships Management and Department of Municipal Affairs and Transport Quality. It is found that Relationships Management correlate significantly with Department of Municipal Affairs and Transport Quality because C.R value $=5.266 \geq 1.96$. Furthermore, C.R positive value is statistically significant $\left(\varrho \leq 0.000,{ }^{* * *}\right)$,

\section{Conclusions}

The study is academically justified. There is a dearth of comprehensive study in academia on the function of total quality management in boosting an organization's performance. The rationale for TQM is hinged on the need of quality planning. Historically, research 
has been conducted on the development and usage of quality reward systems. It has been shown that traditional paper-based methods of managing an organization's performance are unproductive. This is a lengthy and tedious procedure. Numerous aspects have been recognised as necessary for a high-quality, sound organisational product. Total quality management research has examined several aspects of system design, development, implementation, and maintenance. Nonetheless, the studies have fallen short of evaluating all important methodologies for the design, development, implementation, assessment, and management of systems projects using genuine institutional experiences.

The product's quality and achievement of the strategic objective will be determined by the organization's ability to continue offering internet telecommunications products in an efficient and sustainable way. At this stage, the study adds to the gap in the literature review by defining the methods and tests for attaining, controlling, predicting, and confirming plan success. The rationale for TQM is hinged on the need of quality planning. The product's quality and achievement of the strategic objective will be measured by the organization's ability to continue supplying a highquality product in an effective and sustainable way. At this stage, the study adds to the gap in the literature review by defining the methods and tests for attaining, controlling, predicting, and confirming plan success.

The increasing demand for company establishment emphasises the importance of total quality management and organisational performance. With the successful conclusion of this study, businesses must ensure that they use total quality management methodologies in order to ensure their performance. The implementation of the ISO 9001: 2015 system improves the operations of an organization's departments while taking the vertical business structure into account. This study demonstrates ways that ensure businesses use tactics for measuring and monitoring quality development. This may be accomplished through reporting on processes based on feedback systems and metric scores. Similarly, this study demonstrates that adopting ISO 9000 standards enables organisations to develop their own culture of excellence and customer satisfaction. This is done only to surpass the expectations of customers, employees, and stakeholders. The partnership model is founded on an economic structure that enables businesses to make strategic choices focused on increasing quality and productivity. The study also serves as a challenge to policymakers to develop policies that may be utilised by organisations, business leaders, and other stakeholders to solve the issue of total quality management.

\section{Conflict of Interest Statement}

The authors declare no conflicts of interests.

\section{About the Author}

Marwa Naji Ali Alkhater Albuainain is a PhD candidate at Management and Science University in Malaysia. She was supervised by Professor Dr. Ali Khatibi Dr. S. M. Ferdous Azam and Dr. Jacquline Tham, distinguished academics and researchers at the same 
university. They have substantial industry experience gained from working for multinational corporations. Furthermore, they are outstanding academics with many publications, including books, textbooks, book chapters, journals, conferences, etc. Their successful supervision, research examination, and academic awards have also made them well-known around the world.

\section{References}

Adèr, H. J., Mellenbergh, G. J., \& Hand, D. J. (2008). Advising on research methods: A consultant's companion. Huizen, The Netherlands: Johannes van Kessel Publishing.

Sekaran, U., Cavana, R. Y., Delahaye, B. L., et al. (2003). Applied business research: Qualitative and quantitative methods. John Wiley \& Sons Australia Ltd.

Azam, S. M. F. and Moha Asri A. (2015). Differential Roles between Owner and Manager in Financial Practice That Contributes to Business Success: An Analysis on Malaysian Small Business, Academic Journal of Interdisciplinary Studies, 4 (1 S2): 123134

Azam, S. M. F., Haque, A., Sarwar, A. and Anwar, N. (2014). Training Program Effectiveness of Service Initiators: Measuring Perception of Female Employees of Bank Using Logistic Approach, Asian Research Journal of Business Management, 1 (2): 98-108

Browne, M. W., \& Cudeck, R. (1993). Alternative ways of assessing model fit. In K. A. Bollen\& J. S. Long (Eds.), Testing structural equation models (pp. 445-455). Newbury

De Silva, A. D. A., Khatibi, A. and Azam, S. M. F. (2017). Do the Demographic Differences Manifest in Motivation to Learn Science and Impact on Science Performance? Evidence from Sri Lanka, International Journal of Science and Mathematics Department of Municipal Affairs and Transport, 16(S1), 47-67

Dewi, N., Azam, S. M. F. and Yusoff, S. K. M. (2019). Factors influencing the information quality of local government financial statement and financial accountability, Management Science Letters, 9 (9): 1373-1384

Elias, Victor (2015). The Quest for Ascendant Quality: An Introduction to Contemporary Philosophy and Methods for Strategically Orchestrating the Transformation Towards \& Beyond Quality Excellence in Everything you do. Sparta, NJ U.S.A. p. 51

Haque A., Sarwar, A., Azam, S. M. F. and Yasmin, F. (2014). Total Quality Management Practices in the Islamic Banking Industry: Comparison between Bangladesh and Malaysian Islamic Bank, International Journal of Ethics in Social Sciences, 2 (1): 5-18.

Haur, C. H., Khatibi, A. and Azam, S. M. F. (2017). Antecedents of Consumers' Perception towards Online Advertising in Malaysia: The Structure Equation Modeling Approach, European Journal of Management and Marketing Studies, 2 (3): 15-30 
Jayasuriya, N. A. and Azam, S. M. F. (2017). International Review of Management and Marketing, 7(5), 178-183.

Katukurunda, K. G. W. K., Yajid, S. M. A, Khatibi, A. and Azam, S. M. F. (2019). Clients' Satisfaction towards Biosystems Technology; Does Programme Quality Matters? (Evidence From Sri Lankan Perspectives), European Journal of Open Department of Municipal Affairs and Transport and E-learning Studies, 3 (2): 174-190

Khadijah Mohammed Alzhrani, Bashayer Ali Alotibie, Azrilah Abdulaziz (2016). Total Quality Management in Saudi Department of Municipal Affairs and Transport, International Journal of Computer Applications (0975 -8887) Vol. 135(4).

Kumar, V., Choisne, F., de Grosbois, D. \& Kumar, U. (2009). Impact of TQM on company's performance, International Journal of Quality \& Reliability Management, Vol. 26(1), pp.23-37.

Kuruwitaarachchi, N., Yajid, S. M. A, Khatibi, A. and Azam, S. M. F. (2019). Enhance the use of Internet Based Advanced Communication Technologies in Small and Medium Scale Enterprises in Sri Lanka, European Journal of Social Sciences Studies, 3 (2): $44-57$

Maghfuriyah, A., Azam, S. M. F. and Shukri, S. (2019). Market Structure and Islamic Banking Performance in Indonesia: An Error Correction Model, Management Science Letters, 9 (9): 1407-1418

Nguyen, H. N., Tham, J, Khatibi, A. and Azam, S. M. F. (2019). Enhancing the Capacity of Tax Authorities and its Impact on Transfer Pricing Activities of FDI Enterprises in Ha Noi, Ho Chi Minh, Dong Nai, and Binh Duong Province of Vietnam, Management Science Letters, 9 (8): 1299-1310

Pambreni, Y., Khatibi, A., Azam, S. M. F. and Tham, J. (2019). The Influence of Total Quality Management toward Organization Performance, Management Science Letters, 9 (9): 1397-1406Park, CA: Sage.

Poksinska, Bozena; Dahlgaard, Jens Jörn; Antoni, Marc (2002). The state of ISO 9000 certification: A study of Swedish organizations. The TQM Magazine. 14 (5): pp.297-309.

Pushpakumara, W. D. H., Atan, H., Khatib, A., Azam, S. M. F. and Tham, J. (2019). Developing a Framework for Scrutinizing Strategic Green Orientation and Organizational Performance with Relevance to the Sustainability of Tourism Industry, European Journal of Social Sciences Studies, 4 (3): 1-18

Rachmawati, D., Shukri, S., Azam, S. M. F. and Khatibi, A. (2019). Factors Influencing Customers' Purchase Decision of Residential Property in Selangor, Malaysia, Management Science Letters, 9 (9): 1341-1348

Rad, A. M. M. (2006). The impact of organizational culture on the successful implementation of total quality management, The TQM Magazine, Vol. 18(6), p. 606-625.

Tarofder, A. K. and Azam, S. M. F. and Jalal, A. N. (2017). Operational or Strategic Benefits: Empirical Investigation of Internet Adoption in Supply Chain Management, Management Research Review, 40 (1): 28-52 
Tarofder, A. K., Haque, A., Hashim, N., Azam, S. M. F. and Sherief, S. R. (2019). Impact of Ecological Factors on Nationwide Supply Chain Performance, Ekoloji, 28(107): 695-704

Tham, J., Yazid, M. S. A, Khatibi, A. A. and Azam, S. M. F. (2017). Internet and Data Security - Understanding Customer Perception on Trusting Virtual Banking Security in Malaysia, European Journal of Social Sciences Studies, 2 (7): 186-207

Timothy A. Brown (2006). Confirmatory Factor Analysis for Applied Research, 2nd Edition, Guilford Press Publishing. New York, USA.

Udriyah, U., Tham, J. and Azam, S. M. F. (2019). The Effects of Market Orientation and Innovation on Competitive Advantage and Business Performance of Textile SMEs, Management Science Letters, 9 (9): 1419-1428. 

distribute, transmit or adapt the article content, providing a proper, prominent and unambiguous attribution to the authors in a manner that makes clear that the materials are being reused under permission of a Creative Commons License. Views, opinions and conclusions expressed in this research article are views, opinions and conclusions of the author(s). Open Access Publishing Group and European Journal of Economic and Financial Research shall not be responsible or answerable for any loss, damage or liability caused in relation to/arising out of conflict of interests, copyright violations and inappropriate or inaccurate use of any kind content related or integrated on the research work. All the published works are meeting the Open Access Publishing requirements and can be freely accessed, shared, modified, distributed and used in educational, commercial and non-commercial purposes under a Creative Commons Attribution 4.0 International License (CC BY 4.0). 